\title{
Conditionality, Separation, and Open Rules in Multilateral Institutions
}

\section{Paola Conconi}

CSGR, University of Warwick

CSGR Working Paper No. 85/01

December 2001

\begin{abstract}
We examine the implications for the viability of multilateral cooperation of different legal principles governing how separate international agreements relate to each other. We contrast three alternative legal regimes: conditionality - making cooperation in one area a condition for cooperation in another - separation - forbidding sanctions in one area to be used to enforce cooperation in others - and open rules, i.e. absence of any restriction on the patterns of cross-issue cooperation arrangements and sanctions. As an example, we focus on a scenario where countries can enter into selective and separate binding trade and environmental agreements with different partners. Our analysis suggests that conditionality is more likely to facilitate multilateral, multi-issue cooperation in situations where the environmental policy stakes are small relative to the welfare effects of trade policies; when the costs of environmental compliance are high, a conditionality rule can hinder multilateral cooperation. Separation can undermine cooperation by limiting punishment, but can also promote broad cooperation by making partial cooperation more difficult to sustain. Thus, how different linkage regimes affect multilateral negotiations depends on the structure of cooperation incentives for the countries involved.
\end{abstract}

KEYWORDS: Multilateral Cooperation, Conditionality, Separation, Open Rules.

Address for correspondence:

Paola Conconi

Department of Economics

University of Warwick

Coventry, CV4 7AL, United Kingdom.

Tel: +44 (0)24 76572857.

Fax: +44 (0)24 76523032 .

E-mail: P.Conconi@warwick.ac.uk.

Homepage: http://www.warwick.ac.uk/ ecren.

We wish to thank Robert Staiger, Josh Ederington and Nuno Limão for their comments and suggestions on an earlier version of this paper. Any errors are entirely our responsibility. 


\section{Introduction}

The increasing economic and social interdependence between nations has intensified the need for international coordination of policies, both in the economic sphere and outside it. This is achieved through internationally agreed upon rules of international law, often embodied in international institutions, such as the GATT/WTO, the International Monetary Fund (IMF), the International Bank for Reconstruction and Development (IBRD), various UN bodies such as UNCTAD and UNDP, as well as specialized organizations such as the Bank for International Settlements (BIS), WCO, ITU, WIPO, FAO, and the ILO.

Typically such rules and institutions each focus on a specific policy dimension, and are the result of separate negotiations. In some cases, however, multiple policy dimensions are dealt with by a single piece of international legislation or covered by a single agreement. For example, The World Trade Organization (WTO) provides the framework for the conduct of international trade in good and services and for the protection of intellectual property rights. In other cases, agreements and rules in different areas remain formally distinct but contain provisions regulating their interaction. For example, the General Agreement on Tariffs and Trade (GATT) allows member countries to take measures which it considers necessary for the protection of its essential security interests as well as those which taken in pursuit of its obligations under the United Nations Charter for the maintenance of international peace and security. Sometimes we observe distinct rules and agreements, which contain no formal mention of each other, coming into being as a result of joint negotiation. An example is the changes in patent and royalty regulations, energy pricing, and energy supply arrangements that were negotiated between Canada and the US in the 1980's concurrently with (albeit not jointly with) the Canada-US Free Trade Agreement (Perroni and Whalley, 2000).

The examples just described represent instances of "linkage" between different dimensions of international cooperation. What does economic theory have to say about such linkage? One of the key insight that economics has brought to the understanding of laws and institutions is the idea of Coasian bargaining. This is the notion that, whatever the initial distribution of legal rights, the interested parties can arrive at a mutually advantageous (and economically efficient) exchange of concessions through bargaining - as long as the pattern of concessions is unconstrained. If multiple issues are on the table, then efficient bargaining may involve exchange of concession across 
different issues. Thus, an economist's idealized picture of the process of international cooperation consists of a single, all-embracing round of negotiation giving rise to a single, all-embracing cooperation agreement.

In reality, a number of practical considerations prevent this idealized outcome from materializing. To begin with, the number of channels through which countries can affect each other is limited, which in turn limits the possibility of finding mutually advantageous forms of exchange; direct cash payments could, in principle, overcome such limitations, but are in practice seldom used to settle international disputes. Negotiations also entails transactions costs, which become more significant the more complex negotiation is - with respect to both the number of parties involved and the number of issues covered; as a result, more limited forms of cooperation may be preferred to broader agreements. Finally, the issues over which international coordination is required cannot all be on the table before negotiations take place: new issues arise over time, and negotiation must therefore evolve through progressive steps, each adding to (and possibly modifying) previous arrangements.

The actual picture of the institutions through which international cooperation takes place bears little resemblance to the economist's idea of a single all-encompassing arrangement; rather, it is a patchwork of preferential agreements and issue-specific treaties. International cooperation is limited to certain areas: at the time of writing, for example, there is still no fully functioning international agreement for curbing greenhouse emissions. Even when simultaneous cooperation across different areas is achieved, it is usually dealt with by separate rules and agreements. Not only are certain areas excluded from existing agreements; countries also are excluded. Membership in the WTO, for example, is still limited, and there exist a number of preferential agreements (trade and otherwise) involving a small number of partners. In some cases, a country cooperates with a certain set of partners in a certain are, and with a different set of partners in another.

Nevertheless, even if in practice cooperation must be pursued in a piecewise fashion, the results achieved by a given web of arrangements can still be evaluated against the results that could be hypothetically achieved through a multilateral, multiple-issue agreement: replicating such an outcome, within the constraints imposed by the given available instruments and institutions, remains desirable on grounds of economic efficiency. The question then naturally arises of how cooperation agreements in different 
areas should be interfaced so as to facilitate the establishment of multilateral cooperation across multiple areas, given that possibilities of cooperation in one are not independent of cooperation in the other. For example, since the Uruguay Round of GATT/WTO trade negotiations there has been an intense debate over the potential overlaps between trade and nontrade objectives, especially with respect to environmental protection and workers' rights. Should trade sanctions be used to buttress environmental policy cooperation or promote more stringent labor standards? Or should the GATT/WTO forbid the use of trade sanctions to enforce nontrade agreements?

In this chapter, we examine the implications for the viability of multilateral cooperation of different legal principles governing how separate international laws and agreements relate to each other. We contrast three different possible legal regimes: conditionality - making cooperation in one area a condition for cooperation in another - separation - forbidding sanctions in one area to be used to enforce cooperation in others - and open rules, i.e. absence of any restrictions on the patterns of cross-issue cooperation arrangements and sanctions.

To analyze the impact of these different legal regimes on multilateral negotiations and the prospects for achieving cooperation over multiple issues, we focus on a scenario where countries are linked by international trade and transboundary pollution. Following the theoretical framework presented in Conconi and Perroni (2001), we describe a setting where countries can enter into selective and separate binding agreements with different partners along different policy dimensions, and examine the effects of conditionality/separation/open rules on the robustness of simultaneous multilateral cooperation arrangements on both trade and environmental policies.

We conclude that conditionality is more likely to facilitate multilateral, multi-issue cooperation in situations where the environmental policy stakes are small relative to the welfare effects of trade policies and when partial environmental coordination is preferred to no cooperation by all countries involved - implying that outsiders can free-ride effectively on partial environmental agreements. On the other hand, when the costs of environmental compliance are high but the ability to free-ride on partial environmental agreements is limited, a conditionality rule can hinder multilateral cooperation by making it both attractive and viable for a single country to remain outside of any agreement. Separation can undermine cooperation because it limits the channels through which countries can "punish" defectors. However, for the same reason, sep- 
aration can undermine the viability of coordinated responses to unilateral defections countries, and, through this channel, make defections less attractive. Again, the latter scenario requires that the incentives to free-ride on an environmental agreement be sufficiently large in comparison with the gains from trade policy cooperation. The broad message that emerges from this analysis is that one cannot draw general conclusions about the effects on multilateral negotiations of different legal linkage rules: whether the adoption of a certain rule is appropriate for certain areas depends on the specific structure of cooperation incentives in those areas.

The remainder of the chapter is organized as follows. Section 2 briefly reviews the economics literature on issue linkage. Section 3 examines the impact of different negotiation rules on the sustainability of multilateral cooperation. Section 4 looks at examples of how such negotiation rules are embodied in different treaties and institutional arrangements. Section 5 briefly discusses how taking into account the emergence of new issues, transaction costs, and the time horizon of policymakers could affect our analysis. Section 6 summarizes and concludes.

\section{The Literature on Issue Linkage}

The theoretical literature on cross-issue international cooperation has considerably grown in size in recent years, but the term "issue linkage" is used in this literature to denote a number of very different mechanisms.

A strand of this literature has stressed direct strategic linkages, in the sense that different policy instruments may be either close substitutes (meaning that commitments in one policy dimension can easily be undone by adjustments in the other) or complements (meaning that commitments in one policy dimension are ineffective unless accommodated by adjustments in the other). Here, there is clearly a need for joint negotiation: if two types of policies are perfect substitutes, then cooperation agreements reached over a single issue will be fully ineffective absent cooperation in the other. Copeland (1990), for example, examined the case of tariff negotiations when a secondary form of trade barrier (e.g. a non-tariff barrier) is set non-cooperatively. He shows that trade liberalization will induce substitution towards the less efficient, non-negotiable instrument of protection, due to countries facing unilateral incentives to maintain trade protection. In this framework, the two types of trade instruments 
are imperfect substitutes for each other, and lack of cooperation with respect to one instrument directly undermines any cooperation achieved with respect to the other.

Issue linkage has also been proposed as a means of handling asymmetries among countries, when meaningful exchange of concessions can only take place if more that one issue is involved. As noted above, this idea stems from the more general notion of Coasian bargaining. It was first stressed by Raiffa (1982) and Sebenius (1983) in the political science literature, and by Folmer et al (1993), Cesar and Zeeuw (1996), and Abrego et al. (2001) in the economics literature. Although monetary side-payments across countries represent a more efficient means of facilitating international cooperation in the presence of countries' asymmetries, issue linkage will be beneficial when such side-payments are not available.

Another strand of literature has analyzed linkage in situations where agreements cannot be enforced by an external authority, and must be therefore self-enforcing through repeated interaction between countries by the threat of reversion to noncooperation. In this context, a linked agreement is one for which a defection in any dimension of the agreement will trigger a retaliatory response over all dimensions. Spagnolo (1996) shows that removing the possibility of using cross-issue punishment strategies by delegating policies to independent bodies can facilitate cooperation if policy issues are complements in the governments' objective function, but can hinder cooperation if policy issues are substitutes. Limão (2000) finds that linked punishment under repeated interaction and lobbying can lead to a "reallocation of enforcement power" from one policy dimension to the other. With reference to trade policies, Ederington (2001) shows that, when countries can use domestic policies as a secondary trade barrier, a tariff is the most efficient instrument for supporting cooperation under repeated interaction.

What most of the contributions to this literature have in common is that they focus on bilateral relations rather than multilateral cooperation - a notable exception being Maggi (1999). There exists a literature on multilateral cooperation, but most of this literature does not examine cooperation across multiple issues. As we explain below, cross-issue cooperation amongst multiple countries involves forms of negotiation linkage which are not present in the case of bilateral agreements.

The question of how different legal regimes, such as conditionality and separation, affect cooperation has been only touched upon in the above-mentioned theoretical 
literature. In particular, while the implications of separation have been examined with respect to self-enforcing bilateral agreements (by the Spangolo and the Limão papers), conditionality has little meaning in a bilateral world - since preferential cooperation is not an option in such framework - and therefore has not been studied in that literature on bilateral cooperation.

\section{Conditionality, Separation, and Open Rules and their Im- pact on Multilateralism}

In this section, we analyze multilateral policy cooperation choices when international policy coordination is required across multiple issues. Following Conconi and Perroni (2001), the establishment of cooperation arrangements can formally be described as a two-stage process in which binding agreements are formed in the first stage through a sequence of proposals and counterproposals, and policies are selected in the second stage - cooperatively among countries participating in an agreement and non-cooperatively between countries belonging to separate agreements.

To accommodate for the possibility of individual countries belonging to multiple agreements, we draw a distinction between agreements, by which members coordinate their choices along one or more policy dimensions, and coalitions of countries during the negotiation phase, which can make coordinated objections to a proposed cooperation structure. The two concepts are distinct: agreement structures determine the actual policies chosen after cooperation choices are made; whereas coalitions of players can object to a proposed cooperation arrangement by proposing an alternative cooperation arrangement, affecting the structure of agreements - which, in turn, affects policy choices. A viable agreement structure must be immune from objections, and viable objections must be not only profitable for the objecting coalitions but also immune from further external or internal objections, i.e. they must involve arrangements that are themselves immune from objections.

Using this construct, we discuss how the viability of a multilateral, multi-issue agreement (an agreement where all countries jointly cooperate across all policy dimensions) is affected by three alternative legal regimes: conditionality, separation, and open rules. With open rules, countries can enter into selective and separate binding agreements with different partners along different policy dimensions. This means that 
single-issue agreements can both be proposed and used as counterproposals during negotiations. Conditionality makes participation in a cooperation agreement concerning a certain policy dimension a necessary condition for being admitted as a member to a cooperation agreement in another dimension; in other words, cooperation must take place simultaneously across multiple issues, ruling out single-issue agreements. Again, such restriction will affect both the proposals that can be made and the counterproposals that can be made as objections to a proposed cooperation structure. Separation concerns the use of sanctions along a certain policy dimension against countries which do not cooperate along another. In our abstract framework, this means that countries that unilaterally choose not to participate in a multilateral cooperation agreement along one policy dimension cannot be "punished" by being excluded from cooperation in another.

For concreteness, the discussion that follows will focus on a specific scenario where countries are linked by international trade and transboundary pollution. In this context, it has been suggested that multilateral cooperation could be enhanced by formally combining different issues with the aim of joint settlement. ${ }^{1}$ This would correspond to our notion of conditionality. At the same time, there has been much discussion about the legality of using trade sanctions in response to non-compliance to international environmental treaties (see Trebilcock and Howse, 2001). In our framework, a ban on the use of trade sanctions to pursue environmental cooperation goals - and vice-versa - would correspond to a separation regime.

As noted earlier, most of the literature on multilateral policy cooperation has examined cooperation over trade policies and over environmental policies separately from one another. Riezman (1985), Krugman (1991), Bond and Syropoulos (1996), and Yi (1996), among others, have focused on the creation of Customs Unions, while Carraro and Siniscalco (1993), Barrett (1994), and Chander and Tulkens (1992), among others, have focused on International Environmental Agreements. The broad theme emerging from this literature is that the presence of spillovers between coalitions (positive in the case of environmental coalitions, negative in the case of trade coalitions) makes global

\footnotetext{
${ }^{1}$ For example, Carraro, and Siniscalco (1994) point out that environmental free-riding incentives could be offset by making the signing of agreements entailing positive excludable externalities restricted to signatory countries (e.g. trade or R\&D agreements) conditional on environmental cooperation.
} 
cooperation difficult to sustain, and that partial cooperation, restricted to subsets of countries, is more likely to emerge. In our multi-issue cooperation framework, however, the effects of spillovers in different areas become linked, because cooperation incentives in one area can help support cooperation in the other.

Trade policies and environmental policies involve different cooperation incentives and generate different forms of "temptation" to deviate from a multilateral, multi-issue cooperation arrangement. When facing global environmental problems, a country may find it tempting to defect from multilateral environmental cooperation, free-riding on the abatement in global emissions that the remaining countries carry out. In the case of trade policies, a subset of countries may find it optimal to jointly defect from multilateral trade cooperation and form a preferential trade agreement, exploiting the resulting increase in international market power of the trade bloc to the advantage of its members.

In the first case, unilateral free-riding may be avoided if the remaining countries find it optimal, once a country has defected, to dissolve environmental cooperation amongst themselves, which effectively undermines the free-riding attempt. Alternatively, suppose that forming a preferential trade agreement is not attractive if all countries cooperate in environmental policies but becomes attractive if the excluded country also chooses not to participate in environmental policy cooperation. Then, a unilateral defection from environmental cooperation could make a preferential trade agreement between the remaining countries viable, and a country defecting from environmental cooperation could thus be credibly excluded from trade cooperation. If the loss from such exclusion is large enough in comparison with the temptation to free-ride on a multilateral environmental agreement, then multilateral environmental policy cooperation could be sustained.

When the threat to multilateral cooperation comes from incentives to form a preferential trade agreement, environmental policy cooperation incentives could come into play as follows. Suppose that, in the presence of multilateral trade cooperation, a unilateral defection from environmental policy cooperation triggers a dissolution of the environmental agreement amongst the remaining countries, and is therefore not viable; but that, if one country is excluded from trade cooperation, the remaining countries no longer find it optimal to respond to a unilateral defection from an environmental agreement by fully dissolving the agreement. In such scenario, excluding a country 
from trade cooperation induces the excluded country to abandon environmental policy cooperation. Then, the temptation to form a preferential trade agreement may be offset by the need to secure broad environmental policy compliance.

Which of the above scenarios will prevail depends on the specific structure of environmental and trade policy cooperation incentives. For example, the presence of an environmental policy dimension can do little to help support trade cooperation if the costs and gains stemming from trade policies the latter dominate the costs and gains stemming from environmental policies.

The preceding discussion of the linkages between trade and environmental cooperation has focused on a situation where there are no constraints on cooperation patterns: unilateral defections are possible along a single policy dimension, and countries can respond to defections along one dimension by modifying their cooperation arrangements along the other. The presence of a conditionality rule or a separation rule, on the other hand, will limit the range of possible defections (objections) and responses (counterobjections); this will in turn determine which of the above negotiation linkages can be functioning.

Consider, first, conditionality. Starting from a situation where all countries cooperate in both trade and environmental policies, a country will face a temptation to defect from environmental cooperation, but it will lose from being left out of a preferential trade agreement. If the second effect dominates, then conditionality, by linking defection from an environmental agreement to defection from multilateral trade cooperation, can lock in an otherwise reluctant partner within a multilateral, multi-issue cooperation arrangement. On the other hand, if the costs of environmental compliance are large in comparison with the gains from membership in a multilateral trade agreement, then conditionality may not be enough to prevent free-riding in environmental policies. It could, however, limit countries' ability to respond to single-country defections. Given that a country does not participate in the environmental agreement, it may be in the remaining countries' interest to limit their cooperation to trade policy only, dismantling their remaining environmental policy cooperation ties; this, in turn, could undermine the initial free-riding attempt and induce multilateral compliance. Conditionality, by tying cooperation in trade policies to cooperation in environmental policies, makes such a response infeasible, and can thus make unilateral defections viable. 
Similarly, if two countries are tempted to form a preferential trade agreement, conditionality implies that by doing so they have to forgo environmental cooperation with a third country; this may induce them to remain in a multilateral agreement instead. However, suppose now that environmental cooperation incentives are not strong enough to lock in the two countries within a multilateral arrangement in the presence of a conditionality rule. Then, conditionality could constrain the response of the remaining countries to the formation of a preferential trade bloc, and hence make it easier to be established.

A separation regime also limits the pattern of possible responses, as conditionality does, but in a different way: if a country defects from an environmental agreement, it cannot as a result be excluded from a pre-existing trade agreement, and vice-versa. Such separation of responses may undermine cooperation by making unilateral defections from an environmental treaty less costly for defectors; or, it may have no effect on cooperation outcomes if the temptation to defect along the environmental policy dimension is large comparatively to the trade sanctions that would be incurred under open rules. Similarly, if we consider the temptation for two countries to form a preferential trade bloc, separation could make it unfeasible for the excluded country to respond by defecting from the environmental agreement, which in turn could make the formation of the trade bloc more viable. In the situations just described, separation can hinder multilateral cooperation.

However, it is also possible for a separation regime to produce the opposite effect. For example, suppose that a country is tempted to free-ride on an environmental agreement only if the remaining countries manage to maintain environmental policy cooperation amongst themselves (finding it optimal to do so), but not if a unilateral defection causes the environmental agreement to unravel. In this situation, a ban on trade sanctions could make it more difficult to maintain environmental cooperation amongst the remaining countries and may therefore discourage free-riding in the first place. Again, this can only be the case if free-riding incentives are large relative to trade policy cooperation incentives.

The overall conclusion we can draw from the above analysis is that rules must be assessed not just with respect to their effects on defections from multilateral cooperation (the objections), but also for their effect on the viability of coordinated responses to such defections (counterobjections). In some cases, a rule may limit the temptation 
to defect - thus facilitating the establishment of multilateral cooperation; in others, the same rule may limit the range of possible responses to defectors - thus hindering the viability of multilateral cooperation arrangements.

Conditionality is more likely to facilitate joint multilateral cooperation over trade and environmental policies in cases where the environmental policy stakes are small relative to the effects of trade policies, and when partial environmental coordination is preferred to no cooperation by all countries involved - implying that outsiders can free-ride effectively on partial environmental agreements. On the other hand, when the costs of environmental compliance are high but the ability to free-ride on partial environmental agreements is limited, a negotiation tie-in restriction can hinder multilateral cooperation by making it both attractive and viable for a single country to remain outside of any agreement. Conversely, separation is more likely to be an obstacle to cooperation when the environmental policy stakes are small in comparison with the effects of trade policies; when the environmental policy stakes are comparatively large, on the other hand, separation may facilitate multilateral cooperation by making limited forms of environmental cooperation less viable.

If we apply these insights to the current debate about trade and environment, then we should conclude that a conditionality regime across trade and environmental agreements may be helpful to elicit cooperation for relatively "small" environmental issues; and a separation regime may be hurtful to cooperation in these cases. When larger costs and gains are involved in environmental protection - as in the case of policies for addressing global climate change - then conditionality could be a hindrance to cooperation, and a separation regime may actually be appropriate. These conclusions are consistent with what seems to be a widespread view in policy circles with respect to global climate treaties, namely that global trade and environmental institutions should remain separate rather than combined into a single WTO/WEO (World Environmental Organization) system.

\section{Conditionality, Separation, and Open Rules in International Law}

How can the three different linkage regimes discussed above be embodied in international laws and institutions? In this section we examine different possible approaches 
to the implementation of such rules, and provide examples of current practice.

\subsection{Conditionality}

Conditionality has often been used in the context of international aid policy. One of the problems that has affected foreign aid programmes in the past is that it they have been improperly targeted, with funds often ending in the hands of corrupt governments rather than being used for developmental purposes. For this reason, since the early 1990s, donors have increasingly made official development assistance conditional on political and administrative reform, improved human rights regulation, environmental protection, disarmament, etc. (see Hopkins, 2000). This form of conditionality, however, does not correspond the multilateral version of conditionality that has been discussed above, and is therefore more aptly described as "bilateral" conditionality.

Multilateral, cross-issue conditionality in international cooperation can be achieved by a negotiated rule restricting membership to a certain agreement to countries which also participate in another agreement or abide by certain international rules. This can also be implied by the agenda and format of international negotiations (see Jackson, 1997). In the Uruguay Round, for example, differently from previous trade liberalization rounds, it was decided at the outset that the bulk of the multilateral agreements negotiated had to be accepted as a whole. ${ }^{2}$ The "single undertaking" of the Uruguay Round includes, among others, the Agreement on Agriculture, the Agreement on TradeRelated Aspects of Intellectual Property Rights (TRIPs), and the agreement on trade in services (GATS). ${ }^{3}$ Similarly, certain political groups within the United States and Europe would like the next round of GATT/WTO trade negotiations in Doha, Qatar,

\footnotetext{
${ }^{2}$ Before the Uruguay Round, some agreements related to GATT 1947 had been negotiated during previous negotiating rounds. In particular, a number of agreements were negotiated during the Tokyo Round, in the area of non-tariff barriers. These agreements, however, were not adopted by all the contracting parties to the GATT, and were only applied to those countries who accepted to be bound by them.

${ }^{3}$ Four specific agreements are binding only on those Members who have accepted them. These agreements, referred to as the "purgatorial trade agreements", are the Agreement on Trade in Civil Aircraft, the Agreement on Government Procurement, the International Dairy Agreement and the International Bovine Meat Agreement (the latter two of which were terminated at the end of 1997).
} 
to be a vehicle for promoting non-trade objectives - such as labor and environmental standards, gender equality, or social engineering - jointly with trade objectives. ${ }^{4}$

Conditionality can also take the form of rules prescribing that violations of international rules in a certain area be met by sanctions in other areas. Such conditionality rules can be found to be at work within certain multilateral environmental agreements (MEAs). For example, the Convention on International Trade in Endangered Species (CITES), the Basel Convention on the trade or transportation of hazardous waste across international borders, and the Nuclear Non-Proliferation Treaty do not merely permit, but require the use of trade restrictions as an instrument of environmental protection.

\subsection{Separation}

One way of achieving separation between different negotiation issues would be to delegate different policies to independent agents (see Spagnolo, 1996). Governments could thus "tie their hands" by not allowing agents to condition strategies in one game on the history of the other. It should be noted, however, that policy delegation is rarely used with in international economic relations, and that international negotiations almost always involve government representatives rather than independent national agencies. One of the main problems with this separation mechanism is that delegation can only work if governments are able to credibly commit to it, since governments typically face ex-post incentives to regain control of policies and renege on earlier promises if they can do so.

An alternative mechanism for achieving issue separation is to explicitly prescribe separation in international agreements. For example, Article XX of the GATT does recognize the importance of a sovereign nation being able to pursue certain non-trade goals even when such action otherwise conflicts with various obligations relating to international trade. However, it establishes that the use of trade measures should not be "applied in a manner which would constitute a means of arbitrary or unjustifiable

\footnotetext{
${ }^{4}$ The Bush administration has still not been able to win the "fast-track" trade negotiating authority from Congress due to the fact that the present bill "falls short in safeguarding labor rights and environmental standards" (Financial Times, November 7, 2001).
} 
discrimination between countries where the same conditions prevail, or a disguised restriction to international trade." Below, we discuss two examples of explicit separation between trade and other policy areas - namely, environmental protection and labor rights - in international treaties.

\subsubsection{Trade and Environment}

Among the classes of measures listed in Article XX of the GATT, are those "necessary to protect human, animal or plant life or health" $(\mathrm{XX}(\mathrm{b}))$ and those "relating to the conservation of exhaustible resources if such measures are made effective in conjunction with restrictions on domestic production or consumption" (XX $(\mathrm{g})$ ). However, jurisprudence in this area has established a general principle of separation between trade measures and global - rather than domestic - environmental objectives.

The application of article XX to the environment was addressed in several GATT and FTA Panel decisions during the 1980s and early 1990s. The most influential panel ruling in this area relates to the so-called Tuna-Dolphin dispute between Mexico and Canada over the extra-territorial application of the US Marine Mammal Protection Act. This requires steps to be taken to curtail the incidental killing of marine mammals by commercial fishermen. In 1988 the US government introduced an import ban on tuna harvested in a way that did not satisfy the standards for the protection of dolphins applied to domestic fishermen. In 1991 a panel requested by Mexico ruled that the US ban was a violation of GATT article III, and that the Article XX exceptions in GATT could not be applied on an extra-territorial basis, i.e. GATT rules do not allow one country to take trade action for the purpose of attempting to enforce its own domestic laws in another country - even if it is to protect animal health or exhaustible natural resources. The reasoning behind this ruling was that, if the US arguments were accepted, any country could ban imports of a product from another country merely because the exporting country has different environmental, health and social policies from its own. This would create a virtually open-ended route for any country to apply trade restrictions unilaterally - and to do so not just to enforce its own laws domestically, but to impose its own standards on other countries. The door would be opened to a possible flood of protectionist abuses. This would conflict with the main purpose of the multilateral trading system, namely to achieve predictability through trade rules. The Panel also claimed that the language of "necessity" in Article 
$\mathrm{XX}$ (b) meant that a country would have to show that it had exhausted all options less restrictive than trade before resorting to import restrictions and noted that the United States had not exhausted the possibility of international cooperation with respect to dolphin conservation. Given this interpretation of Articles $\mathrm{XX}(\mathrm{b})$ and $\mathrm{XX}(\mathrm{g})$ by the jurisprudence, there is little textual basis for the reading that they allow trade measures to be adopted for enforcing international policy cooperation over global environmental issues.

There are also about two-hundred multilateral environmental agreements (MEAs) currently in force outside the WTO, dealing with various environmental issues. About twenty of these include provisions that can affect trade, banning trade in certain products, or allowing countries to restrict trade in certain circumstances. What is the relationship between the GATT/WTO agreement and these environmental agreements and conventions? The official position of the WTO Committee on Trade and Environment is that trade restrictions are not necessarily an effective instrument of environmental protection, and that the environmental agreements themselves, not trade sanctions, are the most appropriate way to deal with international environmental problems, possibly in conjunction with helping countries acquire environmentally-friendly technology, giving them financial assistance, providing training, etc.

\subsubsection{Trade and Labor Rights}

The interaction between trade policy and labor rights is one if the most contentious issues that the world trading system faces today. ${ }^{5}$ Critics of free trade have argued that it is unfair that producers in industrialized countries should have to compete with imports from countries with much lower wage rates and poorer labor standards. In contrast, advocates of free trade often view differences in countries' labor regulations as a legitimate source of comparative advantage or disadvantage. Aside from competitiveness-based arguments, trade restrictions could also be justified as a means of inducing recalcitrant governments to meet a given set of labor standards. This may involve trade restrictions being imposed in the case of a country violating existing international agreements such as conventions of the International Labor Organization

\footnotetext{
${ }^{5}$ For a discussion, see Hughes and Wilkinson (1998) and Srinivasan (1998).
} 
(ILO), or to induce a country to adopt new standards or norm.

The GATT contains no explicit provision either permitting or requiring trade actions against labor rights violations. Article XX(e) permits otherwise GATT-inconsistent measures "relating to the product of prison labor." The possibility has been raised that Article XX(a), which permits the use otherwise GATT-inconsistent measures "necessary to protect public morals," might be invoked to justify trade sanctions against products that involve the use of child labor or the denial of basic workers' rights. There is no GATT or WTO jurisprudence on the interpretation of Article XX(a), and on the reference to prison labor in $\mathrm{XX}(\mathrm{e})$. However, it has been suggested that the "fact that Article XX(e) is the only provision explicitly addressing production methods strongly indicates the other Article XX sections were not intended to include measures based on other production methods" (Feddersen (1998), p. 76).

The conclusion that Article XX generally implies a separation regime between trade measures and labor rights issues seems to be in line with the official position of the WTO, as reflected in the declaration that emerged from the 1996 Singapore ministerial meeting. In general, the WTO agrees that certain core labor rights should be globally recognized and protected; however, its fundamental legal mandate is to regulate trade and international protection of labor rights should be primarily the task of the ILO.

\subsection{Open Rules}

As discussed in Section 3, the third form of linkage regime - open rules - simply amounts to the absence of conditionality or separation rules, leaving countries free to enter into selective and separate agreements with different partners along different policy dimensions, and to use the threat of noncooperation in one area to support cooperation in another.

This regime can either be implicit, when an international agreement contains no conditionality or separation rules, or it can be made explicit if an agreement formally recognizes the possibility of cross-issue linkage. Below, we provide two examples of the latter. We also briefly discuss an area of international law where the application of an open rules regime is still debated - namely, the legal interface between trade and environmental agreements. 


\subsubsection{Trade and Security Policy}

Article XXI of the GATT explicitly allows trade measures to be imposed whenever a government considers this "necessary for the protection of its essential security interests," either in time of war or in the case of "other emergency in international relations." Sometimes the attempt to invoke a national security rationale is blatantly unjustified. For example, in 1975 Sweden argued that its import quota for footwear was motivated by national security concerns, because the survival of its domestic footwear was a guarantee against possible shortages of army boots in time of war.

GATT rules have been seldom used to contest economic sanctions imposed for foreign policy reasons. One exception is provided by the United States embargo against Nicaragua in 1985, which was contested by the Nicaraguan government. ${ }^{6}$ More recently, the introduction of the US Cuban Liberty and Democratic Solidarity (LIBERTAD) Act if 1996 - more commonly known as the Helms-Burton Act - introduced restrictions on goods of Cuban origin, as well as possible refusal of entry visas and work permits for non-US nationals who have business interests in Cuba. This led the European Union to request from the WTO the establishment of a Special Panel, which was approved on 20 November 1996; the panel suspended its work in April 1997, after the US and Europe reached a bilateral resolution.

\subsubsection{Trade and Monetary Policy}

When the GATT was drafted in 1947, balance-of-payments (BOP) problems were severe both for developing countries and for countries faced with post-war reconstruction. One of the purposes of the International Bank for Reconstruction and Development (the World Bank) and the International Monetary Fund (IMF) was to assist in post-war reconstruction of devastated economies.

Articles XII and XIV of the GATT explicitly authorize certain trade restrictions when a need related to BOP conditions can be demonstrated. ${ }^{7}$ A number of legal

\footnotetext{
${ }^{6}$ The Panel ruled that the embargo did not violate GATT, and noted that it was precluded from judging the validity of - or the motivation for - the US action (Jackson, 1997).

${ }^{7}$ Article XII can be invoked by all Members, while Article XVIII(b) only by the developing coun-
} 
issues have arisen concerning the interaction between GATT rules on BOP-related trade restrictions and IMF rules (see Trebilcock and Howse, 2001).

\subsubsection{Trade and Environment}

Environmentalists often view trade restrictions as appropriate sanctions for non-compliance with international environmental standards; as a means of imposing such standards when there are none; or a response to the failure of particular nations to engage in negotiations to develop such standards. On one hand, the protection of the global commons is clearly a legitimate concern that should be addressed. On the other hand, it has often been argued that the measures taken to elicit environmental cooperation might undermine trade cooperation.

There have been proposals to review Article XX of the GATT in the sense of allowing the use of trade sanctions in defense of MEAs. For example, in his speech at the WTO High Symposium on Trade and Environment held in Geneva from 15-

tries(defined as those in the early stages of development and with a low standard of living). The basic condition for invoking Article XII is to "safeguard the [Member's] external financial position and its balance-of-payments;" Article XVIII(b) mentions the need to "safeguard the [Member's] external financial position and ensure a level of reserves adequate for the implementation of its program of economic development.". Both Articles refer to the need to "restore equilibrium on a sound and lasting basis". While Article XII mentions the objective of "avoiding the uneconomic employment of resources," Article XVIII(b) refers to "assuring an economic employment of production resources." Article XVIII:B contains somewhat less stringent criteria than Article XII. Article XII states that import restrictions "shall not exceed those necessary (i) to forestall the imminent threat of, or to stop, a serious decline in its monetary reserves" or (ii) "...in the case of a contracting party with very low monetary reserves, to achieve a reasonable rate of increase in its reserves." Article XVIII(b) omits the word "imminent" from the first condition, and refers to an "adequate" level rather than a "very low" level of reserves. Both articles require members to progressively relax the restrictions as conditions improve and eliminate them when conditions no longer justify such maintenance.

The Uruguay Round Understanding of the Balance-of-Payments Provisions of the GATT states that contracting parties imposing restrictions for balance-of-payments purposes should do so in the least trade-disruptive manner and should favor price-based measures, such as import surcharges and import deposits, to quantitative restrictions. It also describes procedures for consultation by the GATT Balance-of-Payments Committee, as well as for notification of BOP measures. 
16 March $1999,{ }^{8}$ Sir Leon Brittan (then Vice President of the European Commission) stressed the need to "be more sure than at present that WTO trade rules accommodate the aims of the parties to MEAs and therefore allow the necessary trade measures to be taken under such a MEA. If to achieve that confidence, we need a new interpretation of, or even a textual amendment to, WTO rules, I believe we should go down that route."

It should be noted that trade measures taken against signatories of MEAs pose no real legal issue for the GATT, as long as the environmental agreement has come into force subsequently to the relevant GATT provisions. This is due to a general principle of public international law, whereby in the event of a conflict between international treaties, the provisions of the later treaty apply (art 30(4b) of the Vienna Convention on the Law of Treaties). However, with respect to trade measures taken against nonsignatories of the environmental agreement who are members of the GATT/WTO, the situation is unclear and is the subject of debate. Some environmental agreements explicitly say that countries that have signed the agreement should apply the rules of the agreement even to goods and services originating from countries that have not. ${ }^{9}$ Whether this is in violation of the WTO agreement remains untested, because so far no dispute concerning the application of such provisions has been brought to the WTO.

\section{Additional Considerations}

The previous discussion has ignored a number of factors and problems that affect real-world multilateral negotiations. In this section we briefly comment on some of these additional aspects of international cooperation, speculating on their possible implications for the comparative effects of different legal cross-issue linkage regimes.

\footnotetext{
${ }^{8}$ See speech $99 / 47$ on the WTO web site.

${ }^{9}$ This, however, would seem to be in contrast with Article $30(4 \mathrm{~b})$ of the Vienna Convention (see Hudec, 1996).
} 


\subsection{Emergence of New Issues}

Our discussion so far has neglected the truly dynamic nature of multi-dimensional international cooperation (as distinct from the idea of repeated interaction on a single issue): changes occurring in the socio-economic environment - technological innovation, institutional changes, demographic change - have a profound impact on international cooperation incentives. An example is provided by the relatively new international cooperation challenges arising from global climate change, a problem which has only come to the fore in the last three decades and which had deeply affected international negotiations in other areas. A more recent example is the recent "turnaround in US foreign policy," following the terrorist attacks of September 11. "The US, by necessity, is suddenly involved in the kind of furious diplomacy it abhorred and thought tedious as recently as two months ago. [...] In his first eight, balmy, months in office, Bush was happily tearing up the Kyoto Protocol, the 1972 Antiballistic Missile Treaty and Biological Weapons Convention, and so on. [...] Now he is constantly in talks with the leaders of other countries." 10

The continuous emergence of new and unforeseen issues significantly alters the picture of multilateral negotiations we have painted earlier. When a new issue arises after agreement has been reached with respect to another, an exchange of concessions across the new and the old issues is only possible if the original agreement is renegotiated. Then, if agreements are binding, the previous agreement would come to represent the "fall-back" position for renegotiation, and thus affect the outcome of renegotiation. This means that countries, when entering into cooperation arrangements, also try to anticipate how current agreements might affect the outcome of any future agreements. Even if we think of international agreements as being not binding but self-supporting (i.e. continuously renegotiated), the status quo of cooperation may still be relevant. Theories of cooperation under repeated interaction predict that many different outcomes are possible; the status status quo could then represents a "focal point" determining which particular outcome prevails.

Different legal linkage regimes may differently affect countries' strategic incentives to position themselves within current agreements so as to affect future negotiations

\footnotetext{
${ }^{10}$ New Statesman, November 12, 2001.
} 
in their favor. For example, one could conjecture that a blanket conditionality rule, forcing countries to cooperate simultaneously over new and old issues, may reduce incentives for entering into a preferential agreement on a certain issue in order to secure a "privileged" platform for negotiating an agreement over a new issue. Separation could have a similar effect, because it would remove countries' ability to threaten changes in existing cooperation arrangements with respect to old issues when negotiating agreements over new issues. More selective conditionality and separation rules, affecting certain dimensions of cooperation and not others, can be more difficult to impose when issues arise sequentially, simply because new issues are unforeseen and therefore cannot be selectively addressed by the provisions of earlier agreements.

\subsection{Transaction Costs}

Our analysis of multilateral negotiations in Section 3 did not account for the existence transactions costs in international negotiations, costs which become more significant the broader negotiation is. For example, since the creation of the GATT in 1947, trade negotiations have become increasingly complex. In the early GATT rounds, where the focus was mainly tariff cuts, and which involved representatives of a few nations only (twenty-three in the first round), negotiations were concluded in a few months. The increase in the number of GATT member countries and in the number of issues to be negotiated upon has led to an increase in the complexity, and hence the duration, of more recent trade rounds. The Uruguay Round involved 117 participants, and its final document, comprising more than 26,000 pages, consisted of no less than nineteen Agreements, twenty-four Decisions, eight Understandings, and three Declarations. ${ }^{11}$ The complexity of the negotiations explains why the Uruguay Round lasted from 1986 until 1994. Disagreement over the issues to be included in the negotiations has led to the collapse of the Seattle Round of GATT/WTO trade negotiations; disagreements with respect to the negotiation agenda have also started to emerge among the 142

\footnotetext{
${ }^{11}$ Decisions were reached in four main areas: tariff reductions in agriculture, textiles and apparel; institutional arrangements covering dispute settlement and the creation of the WTO; trade rules governing subsidies and countervailing duties, safeguards (VERs) and antidumping; and the new areas of services, investment, and intellectual property rights.
} 
countries participating to the new round of trade negotiations recently launched in Doha, Qatar.

Due to transaction costs, more limited forms of cooperation may actually be preferable to broader agreements on grounds of economic efficiency. This means that an inclusive, all-encompassing multilateral cooperation arrangement is not necessarily an ideal model of cooperation; which, in turn, changes how the effects of different linkage rules should be assessed.

\subsection{Self-enforcing Agreements and Myopic Policymakers}

As mentioned earlier, one of the questions that has been stressed in the theoretical literature on international agreements is the problem of their enforcement. In the absence of external enforcement mechanisms, international agreements must be sustainable by the implicit threat of reciprocal punishments between the participating parties. This interpretation typically assumes domestic policymakers to be fully forward-looking. In reality, international policy interaction takes place between elected politicians who remain in office for a limited term. Theoretically, if these "finitely-lived" policymakers behave as forward-looking welfare maximizers, political turnover should not affect international cooperation prospects: sharing a common objective, successive cohorts of policymakers would behave as a single infinitely-lived player. However, if different policymakers have different policy stances - because of intrinsic differences in their policy preferences or because of political pressure or lobbying - then such equivalence breaks down, and the presence of limited terms of office may not be inconsequential for whether and how international policy cooperation takes place.

Specifically, political turnover implies that policymakers in different countries initially have only limited information about each other's incentives to cooperate, and must learn about each other through interaction. Infinitely-lived policymakers would be able to fully infer any relevant information about their opponents from their policy choices within a finite period of time - after which they would interact with each other as fully-informed opponents. Finitely-lived policymakers, on the other hand, have only limited opportunities to learn about each other, and the need to learn arises continuously as new policymakers come onto the scene. When multiple issues are involved, such learning may involve cooperation being established or renewed sequentially across

different issues, with policymakers first cooperating in one area to "test each other" 
with respect to cooperation incentives in other areas. In this context, a conditionality or separation regime would constrain how such learning can take place, and, would, through this channel, affect cooperation prospects.

\section{Summary and Conclusion}

In this chapter, we have examined how legal regimes for the interface between agreements in different areas can affect the prospects to achieve multilateral cooperation. To compare the implications of different legal linkage regimes - conditionality, separation, and open rules - we have focused on a scenario where countries can enter into selective and separate binding trade and environmental agreements with different partners. Our analysis suggests that conditionality is more likely to facilitate multilateral, multi-issue cooperation in situations where the environmental policy stakes are small relative to the welfare effects of trade policies; when the costs of environmental compliance are high, a conditionality rule can hinder multilateral cooperation. Separation can undermine cooperation by limiting punishment, but can also promote broad cooperation by making partial cooperation more difficult to sustain. Thus, how different linkage regimes affect multilateral negotiations depends on the structure of cooperation incentives for the countries involved.

We have provided some examples of how these linkage rules are translated into the letter of international law, and have touched upon certain real-world complications that affect the process of international cooperation, speculating on how they may affect negotiations. It should be stressed that what we have offered here are only conjectures: the literature on cross-issue cooperation in a multilateral environment is still in its infancy, and no theoretical analyses of these issues yet exist.

Finally, it must be remarked that conditionality and separation rules could themselves be viewed as endogenous to the multilateral process, and hence require multilateral support and enforcement. We have noted that such rules are actually embodied in certain international laws and institutions, but our analysis has said nothing about their genesis. Further theoretical research is needed before this question can be addressed. 


\section{References}

Abrego, L.E., C. Perroni, J. Whalley, and R.M. Wigle, 2001, "Trade and environment: bargaining outcomes from linked negotiations," Review of International Economics 9, 414-428.

Bagwell, K., and R.W. Staiger, 1997, Multilateral tariff cooperation during the formation of regional Free Trade Areas, International Economic Review 38, 291-319.

Barrett, S., 1994, Self-enforcing international environmental agreements, Oxford Economic Papers 46, 878-894.

Bond, E., and C. Syropoulos, 1996, Trading blocs and the sustainability of interregional cooperation, in Canzoneri, M.B., W.J. Ethier, and V. Grilli (eds.), The new transatlantic economy (Cambridge University Press), 118-141.

Brack, D., 1997, Trade and environment: conflict or compatibility? (The Royal Institute of International Affairs, London).

Carraro, C., and D. Siniscalco, 1993, Strategies for the protection of the environment, Journal of Public Economics 52, 309-328.

Carraro, C., and D. Siniscalco, 1994, Policy coordination for sustainability: commitments, transfers, and linked negotiations, in I. Goldin, and A. Winters, eds., The economics of sustainable development (Cambridge University Press, Cambridge), 264-282.

Cesar, H., and A. de Zeeuw, 1996, Issue Linkage in Global Environmental Problems, in Xepapadeas, A. (ed.), Economic policy for the environment and natural resources: techniques for the management and control of pollution (Elgar, Cheltenham, U.K. and Lyme, N.H), 158-173.

Chander, P., and H. Tulkens, 1992, Theoretical foundations of negotiations and cost sharing in transfrontier pollution problems, European Economic Review 36, 38898.

Conconi, P., and Perroni, C., 2001, Issue linkage and issue tie-in in multilateral negotiations, forthcoming, Journal of International Economics. 
Copeland, C., 1990, Strategic interaction among nations: negotiable and non-negotiable trade barriers, Canadian Journal of Economics 23, 84-108.

Ederington, J., 2001, International coordination of trade and domestic policies, forthcoming, American Economic Review.

Feddersen, C.T., 1998, Focusing on substantive law in international economic relations: the public morals of GATT's Article XX(a) and "conventional" rules of interpretation, Minnesota Journal of Global Trade 75.

Folmer. H., P. van Mouche and S. Ragland, 1993, Interconnected games and international environmental problems, Environmental and Resource Economic 3, 313-335.

Hopkins, R. F., 2000, The political economy of foreign aid, in F. Tarp, and P. Hjerthom, eds., Foreign aid and development (Routledge, London).

Hudec, R., 1996, GATT legal restraints in the use of trade measures against foreign environmental practices, in J. Bhagwati and R. Hudec (eds.), Fair trade and harmonization: pre-requisites for free trade?, Vol. 2 (MIT Press, Cambridge, MA).

Hughes, S., and R. Wilkinson, 1998, International labor standards and world trade: no role for the World Trade Organization?, New Political Economy 3, 375-89.

Jackson, J.H., 1997, The world trading system: law and policy of international economic relations (MIT Press, Cambridge, MA).

Limão, N., 2000, Trade policy, cross-border externalities, and lobbies: do linked agreements enforce more cooperative outcomes? mimeo, Columbia University.

Maggi. G., 1999, The role of multilateral institutions in international trade cooperation, American Economic Review 89, 190-214.

Perroni, C., and J. Whalley, 2000, The new regionalism: trade liberalization or insurance?, Canadian Journal of Economics 33, 1-24.

Raiffa, H., 1982, The art and science of negotiation (Harvard University Press, Cambridge, MA). 
Riezman, R., 1985, Customs unions and the core, Journal of International Economics 19, 355-365.

Sebenius, J.K., 1983, Negotiation arithmetic: adding and subtracting issues and parties, International Organization 37, 281-316.

Spagnolo, G., 1996, Issue linkage, delegation, and international policy cooperation, Fondazione Eni Enrico Mattei Working Paper No. 49.96.

Srinivasan, T. N., "Trade and Human Rights", 1998, in Constituent interests and U.S. trade policies (University of Michigan Press, Ann Arbor), 225-253.

Trebilcock, M.J., and R. Howse, 2001, The regulation of international trade (Routledge, London and New York).

Yi, S.-S., 1996, Endogenous formation of Customs Unions under imperfect competition: open regionalism is good, Journal of International Economics 41, 151-175. 